
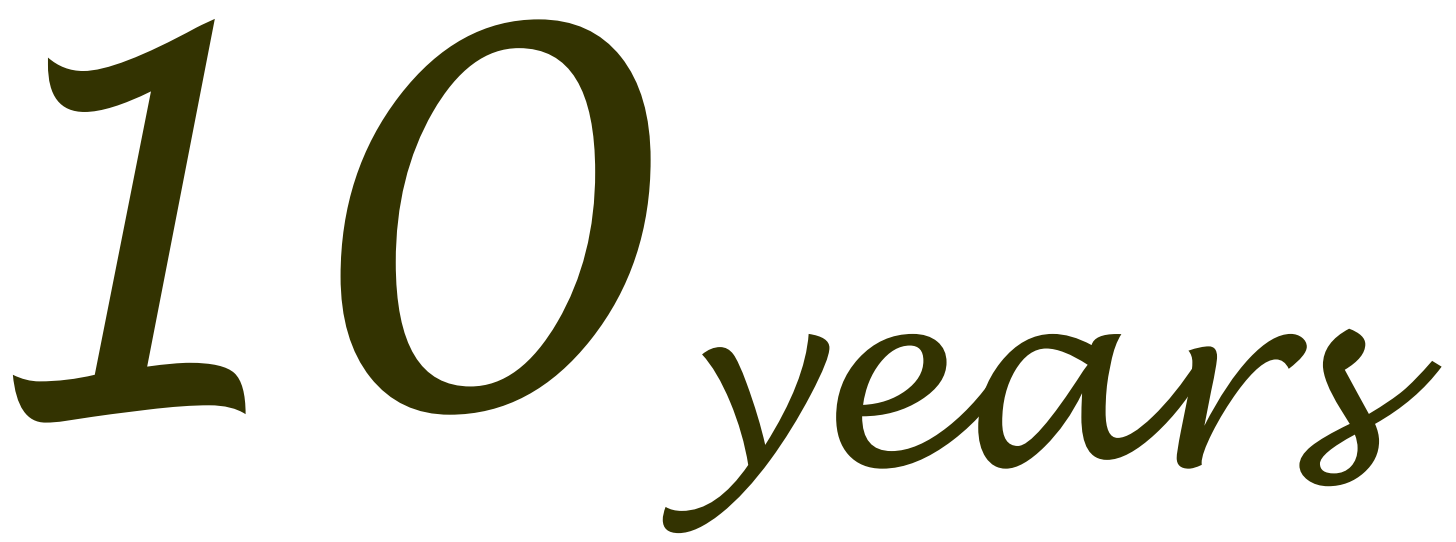

Editors:

Jaime Almansa Sánchez and Elena Papagiannopoulou

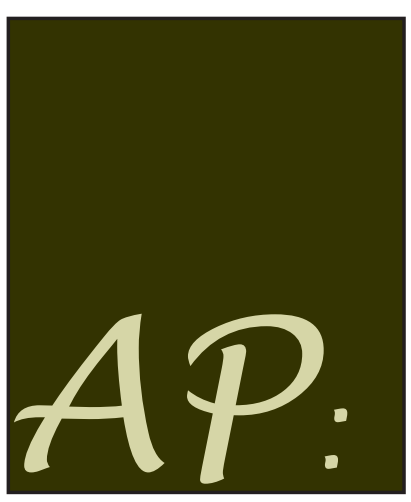

www.arqueologiapublica.es

Ontine Journat in Public Archaeology 


\section{INDEX}

Editorial

Jaime Almansa-Sánchez and Elena Papagiannopoulou

An interview with Tim Schadla-Hall

Tim Schadla-Hall and Jaime Almansa-Sánchez

Points of You:

Is archaeology becoming a bullshit job?

Jaime Almansa-Sánchez

FORUM:

Chatting about the future of public archaeology

Indigenous views on the future of public archaeology in Australia

Kellie Pollard, Claire Smith, Jasmine Willika, Vince Copley senior, Vincent Copley junior, Christopher Wilson, Emily Poelina-Hunter and Julie Ah Quee

Dealing with a hangover of Public Archaeology:

Scattered thoughts on the Italian 'Archeologia Pubblica'

Francesca Benetti

For a solidary and activist [public] archaeology in the Amazon

Marcia Bezerra

From present to future. An academic perspective of Public Archaeology in Spain

Alicia Castillo Mena

Public Archaeology in Nepal: Now and in the next 10 years

Neel Kamal Chapagain 
Public Archaeology in $\mathbf{1 0}$ years? We will hopefully

learn to share more, and better

Sarah De Nardi

When divulgation reaches us

81

Jaime Delgado Rubio

Archaeology in the public space in Nigeria

87

Caleb A. Folorunso

Toward a Decolonial and Denationalized Public

97

Archaeology

Rafael Greenberg

Public Archaeology: the loss of innocence

Reuben Grima

Archaeology for the public in Greece minus/plus ten

Stelios Lekakis

"Let's send millions of qualified public archaeology cadres to the new museums and field units!"

Gabriel Moshenska

After the Pandemic: Reflections from an uncertain present on the futures of public archaeology

Alejandra Saladino and Leonardo Faryluk

How do I see Public Archaeology in ten years in Peru

Daniel Saucedo Segami 
AP: Ontine Journat in Public Archaeology Volume 10 - 2020 p. 19-28

\title{
POINTS OF YOU
}

IS ARCHAEOLOGY BECOMING A BULLSHIT JOB?

\author{
Jaime ALMANSA-SÁNCHEZ \\ Instituto de Ciencias del Patrimonio, CSIC
}

It was summer, I was searching for new books for my to-read pile and I came across Graeber's latest work, Bullshit jobs (Graeber 2018). Right after buying it and reading the short essay it started with, I posted a question on Twitter: "Is archaeology a bullshit job?" Instantly, he answered-without even quoting him in the tweetthat it was not because people valued it. I did not want to engage into a debate, but the question stayed in my head, as I was not so convinced. He suddenly died a few days later. The book was next in my pile and I compulsively finished the one I was reading to start with it as soon as possible. Now, with a forum about the future of public archaeology in this celebratory volume, I thought it would be timely to add this opinion piece to celebrate his memory and react.

\section{On bullshit jobs (and the image of archaeology)}

I will just start with a brief review of what a bullshit job is according to the final working definition offered by Graeber:

"Final working definition: a bullshit job is a form of paid employment that is so completely pointless, unnecessary or pernicious that even the employee cannot justify its existence even though, as part of the conditions of employment, the employee feels obliged to pretend that this is not the case." (Graeber 2018: 9-10).

-Are you f* crazy!? Why do you say archaeology is a bullshit job?

-Wait a second, let me explain... 
-Did you even understand the definition, boy?

-Yes, please, let me explain...

-You are not doing any good stating this... Archaeology IS NOT A BULLSHIT JOB.

- Vale, para tí la perra gorda...

But I will still explain myself. And in order to do so, the second stop will be a brief comment on the types of bullshit jobs that Graeber defines, as well as the levels of bullshitisation there are. You can put on this short video with David explaining, as he does so much better than me:

https://youtu.be/kehnIQ41y2o

So, you can have clearly and fully bullshit jobs, but also those that are just partly or blurrily bullshit (which will be our case). Also, we have flunkies (those who exist to make someone important), goons (those who exist just to coerce), duct tapers (or pure senseless bureaucrats), box tickers (for justifying the work of others) and taskmasters (to make others do stuff). All this, with many combinations and levels makes you think when reading that, indeed, most jobs today are at least partly bullshit.

Now, archaeology as a core concept does not seem to be a bullshit job if you understand the creation of knowledge and heritage is per se valuable for our society. Or so we believe. But let's not question that yet.

We tend to believe most people love archaeology, and most archaeology is a pure concept of archaeology, but that is not the case. People love an image of archaeology and we waste most of our time and resources doing things that are far even from the basic values of our discipline. Let's delve into these ideas... 


\section{From archaeo-appeal to value in real-life archaeological politics}

Holtorf (2005) made popular the concept of "archaeo-appeal" as the-positive-imagination about the past that brought a wide interest in archaeology. However, what archaeology? And I ask this question because for most people archaeology represents basically the romantic image that comes with the concept. Nobody doubts the appeal of great sites, even if some do not enjoy visiting them that much. But what about a pit in the middle of a dirty lot? The tons of pottery sherds even we re-bury?

They are of high value for research, but not that appealing. Indeed, they become a managerial problem even for professionals. In my current project (\#pubarchMED), one of the issues I study is precisely the way sites relate with their surroundings and how we manage this mess (Almansa-Sánchez 2020). From the perspective of the professional, but an eye in the interaction with people, besides many problems and challenges that came across the interviews, one thing remained clear in most of them: If we measure public interest from investment, archaeology is currently undervalued for its needs. Underfunded, underprotected, and with precarity as a norm. In this context, management becomes difficult, bureaucratic and inefficient. And every other aspect of the profession suffers from similar blows.

-Please, stop crying...

-This is not sadness, it's rage. Because we are to blame for this situation, and it is real.

-It has always been like this. But we are doing quite well anyway.

-Mal de muchos, consuelo de tontos...

I cannot settle for this situation. I have the feeling that the main values of archaeology are being forgotten. We produce for a system that only cares about profit (see last analysis in Australia by Smith and Wilson [2020] on the academic side of this, or a prior stand by me [Almansa-Sánchez 2015]), engaged with policies that converted a research-based profession into a mere bureaucracy 
and failing to deliver an archaeological heritage that can actually meet the needs of people, from leisure or culture, to wellbeing. And all this becomes frustrating, and even alienating. Let's see how.

\section{Frustration and alienation in archaeology}

You get into university, expecting dinosaurs and Indiana Jones. The first slap comes with real archaeology, but it is fine, still fascinating. When you finish your studies reality begins. The joy of summer excavations is mostly over, and you are offered two pills: the blue one takes you to commercial archaeology; the red one to Academia. Most get really tempted by the red pill. After all, this is the archaeology we learned, the real one, the scientific one, the one that creates new knowledge about the past. But taking the red pill does not guarantee success... you have to earn it, and most people don't. So, at some point in your live you have to take the blue one or go home and do something different. And it is not that bad, you get paid slightly better, learn more, even feel what you are doing is important. But the feeling usually lasts only a few months. Until you realize what lays behind all these processes (I like to quote Olivier's chapter on the origins of preventive archaeology in France [2016], or even the story behind El Hallazgo, a novel by Pablo Guerra [2012], that we summed up in the PoY of volume 3 [Williams 2013]).

Frustration is a very extended feeling within archaeology. Basically, because it is difficult to assume reality in a context where archaeo-appeal is what built vocation on you. Afterwards, new expectations fail to come real; when you fail in Academia; when you spend part of the year un(der)employed after getting two master degrees or a PhD; when you see your friends with stable lives and yours in the muddy pit on a construction site. If you had to pay for your degree, debt is a nightmare soon. If not, precarity is enough nightmare. But you like what you do, you have a vocational work and maybe do not feel as miserable as others that do not have the privilege of doing what they like for a living.

-You should go to the psychologist...

-Well, I cannot pay for it. 
-At least you didn't lose your sense of humor.

-I guess you learn to value the small things.

-And you are indeed privileged.

-Sarna con gusto no pica...

We often hide behind vocation and hope. At least this is what keeps me going. Still, at some point in your professional life, frustration becomes too heavy. You even consider leaving it all. It is not impostor syndrome; it is plain disaffection. And a part of it comes from the alienation you feel when your expectations-what you truly should be doing-do not correspond to the cornerstone of your daily work.

If something, Covid-19 has also helped to realize this. This race ahead we live, either in Academia or commercial archaeology, needs to be reconsidered, and for some reason we are reluctant to do so (maybe because we know we are going to be the only ones to stop and this will mean losing all chances). The system is so strong that no matter what we really believe, we reproduce it in this last try to stay.

\section{The right to meaningful employment...}

Am I depressed? Not now. Do I want to depress you? Not really. But I want to call for your attention, especially in this moment we have again the opportunity to sit down and think. I strongly believe some sectors of our profession are entering a dynamic of bullshitization and we can still stop it if archaeology is really valuable to people as David said. We are stronger than we think.

-You are really getting me depressed...

-I'm sorry, but I want you to think about this. It is important.

-I mean, I love what I do, but it is true sometimes I feel frustrated.

-Well, like in $A A$, the first step is to recognize it.

-Should be doing an Archaeologists Anonymous thing... 
-Cheaper therapy, indeed.

-But I still don't see this bullshit claim.

- Lo que no se empieza, no se acaba...

Okey, let's see in what ways archaeology is slowly becoming a bullshit job:

\section{Flunkies}

Defining this role within archaeology is not easy because it is not really present. We can feel this way when we are part of a senior's entourage in a conference or a meeting, without voice, just showing up to pretend. I have seen this at some meetings in the Administration too. However, I guess it is more a punctual feeling in a certain moment on bigger structural problems of Academia and Administration than an actual problem of archaeology.

\section{Goons}

I am pretty sure some PhD students might think their supervisors fit in this role, but let's not be cruel. For the moment, this is not a problem in our profession.

\section{Duct tapers}

Here is where things get interesting. Bureaucracy has become a major issue in most spheres of archaeology. Many academics complain about the time wasted in evaluations, and all sorts of bureaucracies that should not fall in their laps, or directly should not need to exist. The system has become so untrusting that you need to certify the certificates you submit for your certification are true, attach photos of your talks in an international conference and copies of the papers anyone can find online with a couple of clicks. My last update for my funder took three full days and a document around 300 pages. This means, with other attached actions in that process, that for this month around 30\% of my working time went to unnecessary bureaucracies that could be easily replaced by a sworn declaration and real consequences for lying in your reports and CV. 
But there is a more serious issue related to commercial archaeology (and even preventive archaeology in some contexts). The frustration I was mentioning above has to do with the relegation of archaeological interventions to mere bureaucratic processes. Not just the process itself, but the action. You find something in the preliminary survey, but it is not going to change the outcome. You excavate to mitigate the damage but will hardly have the time or funds to research whatever comes out. And what is worse... nobody is going to expect you do. Then, your whole role is basically clearing the lot in the process of construction, losing the fundamental values of archaeology. You become a digger and the sites you dig become paperwork and materials in some store, waiting for some actual archaeology to happen.

\section{Box tickers}

This is a necessary consequence of the previous part. Some colleagues just exist to make sure the bureaucracy happens correctly. Actions that could not just be automatized to a great extent, maybe focusing on actual quality and not a list of requirements. But also actions that in many cases should not exist.

\section{Taskmasters}

And this whole process ends up creating middle management positions for an activity with one of the highest rates of PhDs in the job market. This side of the bullshitization of archaeology is probably the most difficult to recognize, but is there.

Still, do not get me wrong. A high percentage of the work we do is relevant and serves a real purpose. I do believe archaeology is not a bullshit job. However, I think that we have fallen in a very dangerous dynamic that affects our profession. We have the privilege of a possibility to be mostly self-regulated and self-organized within the system. This is something very few professions can say. Still, we fall. So please, wake up and do not become bullshit. 


\section{Do not become bullshit!}

Some years ago, I wrote a sort of op-ed in a Spanish journal (Almansa-Sánchez 2014) about the poor outcomes of the 2008 crisis in the very needed reconsideration of our practice. Most of the things I complain about here were in place before that crisis and today, in the brink of a new one with Covid-19, we face the same challenges.

We know our problems. We know how we could solve some of them. Somehow, we do not even try. If the situation was stable, at least we could relax a bit. However, in the last forty years we can see a debilitation of our position that continues as time passes.

Some will say it is not true. Our position is stronger than forty years ago. We have more funding; we reach places we did not even imagine back then; we excavate more, publish more and divulgate more. Maybe in absolute numbers this is true. But the general resources available today are not the same either. We might be in front of the classical quantity over quality statement.

Private funding (mainly for preventive archaeology) is a bargain for developers that get a higher benefit for their money. We have been miserable in the negotiations (trick of tenders) and became the dumb overeducated blocks of the site. Sites are normally destroyed, record inaccessible, heritage invisible (and badly interpreted after the architect used all the money for the architectural enhancement), and our image is still this of the amateur treasure hunter and the romantic big-ruin/relic adventurer.

Our presence in development committees, funding meetings and such is irrelevant. In most cases our advice is not followed and forcing actions (because we actually have that power sometimes) means cessation or other political repercussions. We are just another piece of the political game in which very few strong people actually move well.

And we might probably be more present, but news keep talking about "firsts" and "icons" and "treasures" and find it difficult to make someone understand that those stones next to their homes are actually of value... because most times they are just not. 
So, now we have more thinking time at home, and a bit of self-critique is due, please let's do something. Changing the system is a radical chimera we can aim and never do, but every day counts. Every time you feel frustrated or losing your time with something that would easily fall into the bullshit tag, remember we have the privilege to do what we want, and even do it as we want. Just we cannot do it alone. We need a strong collective to fight for it and make archaeology great again, as Trump would (not) say (tanta paz lleve como descanso deja, to drop a last Spanish saying).

This is the key word: Organize. Go to your professional association or union, get involved, debate, propose and act, start your own, fight for a better archaeology that does not become another bullshit job. No matter where you are or your specific problems. If we are able to build a strong community of professionals with clear goals, maybe all these things we do not like can end with a different outcome.

\section{References}

Almansa-Sánchez, J. 2014. Bendita crisis, maldita profesión. ArqueoWeb 15, 322-325.

Almansa-Sánchez, J. 2015. Trading archaeology is not just a matter of antiquities. Archaeological practice as a commodity. In Gnecco, C. and Lippert, D. (eds.). Ethics and archaeological practice. The politics of social justice. Volume 1. Springer, New York, 141-158.

Almansa-Sánchez, J. 2020. Spaces for Creativity in Mediterranean Archaeological Heritage Management. Advances in Archaeological Practice 8(3), 275-287. DOI: 10.1917/ aap. 2020.21

Graeber, D. 2018. Bullshit jobs. The rise of pointless work and what we can do about it. Simon \& Schuster. New York. [2019 Penguin edition used for reference]

Guerra, P. 2012. El hallazgo. La historia ficiticia de un arqueólogo real. JAS Arqueología Editorial, Madrid. 
Holtorf, C. 2005. From Stonehenge to Las Vegas: Archaeology as Popular Culture. AltaMira Press: Lanham.

Olivier, L. 2016. How I learned the Law of the Market. In Aparicio, P. (ed.). Archaeology and Neoliberalism. JAS Arqueología Editorial, Madrid, 223-238.

Smith, C. and Wilson, Ch. 2020. Research analytics and the corporatisation of Australian universities: Driving quantity but not quality? Australian Archaeology 86(3), 315-317. DOI: 10.1080/03122417.2020.1834191

Williams, L. 2013. From a book to the raw world of archaeology. AP: Online Journal in Public Archaeology 3, 131-133. 


\section{AP: Ontine Journat in Public Archaeology}

Editors:

Jaime Almansa Sánchez \& Elena Papagiannopoulou

Email: almansasanchez@gmail.com

Assistant production editor:

Alejandra Galmés Alba

Edited by:

Asociación JAS Arqueología

Website: www.jasarqueologia.es

Email: jasarqueologia@gmail.com

Address: Plaza de Mondariz, 6, 28029 - Madrid (Spain)

\section{Tenth Anniversary Edition}

Copyleft 2020 Asociación JAS Arqueología (edition) \& Authors (content)

ISSN: 2171-6315

AP Journal is a peer-reviewed journal devoted exclusively to Public Archaeology. It is freely distributed online on the Website:

www.arqueologiapublica.es

You can also follow us on:

Blogger:

\section{$\Xi$}

http://arqueologiapublica.blogspot.com/

Twitter:

http://twitter.com/APjournal

Facebook: 